\title{
NEW EXTENSION AT THE TORRY RESEARCH STATION, ABERDEEN
}

\author{
By Dr. A. BANKS
}

Deputy Director, Torry Research Station, Aberdeen

\section{$\mathrm{O}$} April 6, Lord Fleck, formerly chairman of Imperial Chemical Industries, Ltd., opened the new laboratories of the Torry Research Station, Aberdeen, previously of the Department of Scientific and Industrial Research (Fig. 1). This Research Station was transferred to the Ministry of Technology on April 1.

The Torry Research Station was opened in Aberdeen in 1929 as a direct result of a recommendation by the Imperial Economic Committee in 1927 that research on the preservation of fish should be increased and that a research station should be provided at a fishing port for this purpose. A site was obtained on the south bank of the River Dee, which at one time had been used as a shipbuilding yard. The original office building was modified to provide administration offices and library together with biochemical and bacteriological laboratories. The original fitting-out shed was supplied with an upper floor and the whole was then fitted out with a few labor. atories, engineering and joinery workshops, space for handling fish, including smoking, freezing equipment and a number of cold rooms ranging in temperature from $0^{\circ}$ to $-30^{\circ}$. This conversion was ultimately completed by 1934.

These facilities served the Station's needs very well for a number of years, which saw the development of new techniques for the chilling, freezing and cold-storage and smoke-curing of fish; but with the growth of the Station after the Second World War, it became apparent that there was not nearly enough room for the work being done and for the demands on the Station's resources that were being made at the time. A small building and alteration programme was then begun which involved the provision of a large boiler-house to satisfy foreseeable future requirements, a number of single-storeyed temporary hutments to house workshops, administration offices, library, conference room, etc., and a small laboratory block. Space vacated by staff moving into these new premises was suitably modified for laboratory work. It soon became evident, however, that this kind of expansion was not enough and a start was made on a new permanent building. This was completed in 1954 . The facilities provided here included new and improved equipment for the chilling, freezing and cold-storage and general handling of fish, an engineering test floor and drawing office and three laboratories. Once again, space vacated by staff and facilities as they were moved into the new buildings was suitably modified to provido laboratories and other requirements. Within a few years, this building had to be extended by a single-storeyed structure to house the Bacteriological Section of the Station, which until then had occupied the whole of the original shipyard office-block. It was found that this particular building had outlived its usefulness.

In 1958 , the unsatisfactory nature of the accommodation in the older buildings and in the temporary hutments, coupled with further increases in staff as new commitments were takon on, led to a decision being made to provide sufficient space in a new permanent building to satisfy the needs of the Station as regards laboratories and administrative services for some years to come.

Quite a number of problems were encountered in planning the size and shape of the new extensions. The site on which the Torry Research Station is built is far from ideal. It is small, irregular in shape, with a slope of 1 in 30 towards the river. Provisions had been made in previous building programmes for the buildings to be extended. Thus, the foundations of the single-storeyed extension had been made large enough to carry a further two storeys, and provisions had been made for the steel frame work to be extended upwards and to be tied on to the taller main building. The single-storeyed extension had been built up to the agreed building line, and the aim now was to erect two more storeys on top of this extension and at the same time to join a three-storeyed building at right angles to the main structure at the point where the original extension had been made. It was hoped that in this way it would be possible to provide laboratories and offices for all the scientific and administrative personnel.

Because the Torry Research Station is a Government establishment, the erection of new buildings and modifications become the responsibility of the Ministry of Public Buildings and Works, and before planning can begin they, of course, need a list of requirements in terms of floor areas required for the various purposes. Standards are laid down with regard to offices, but there is no standard requirement for laboratory workers. Previous extensions and modifications had been limited in size by being built within existing structures, or by the space available on the site. Such strictures did not apply to the same degree in the present case, although there was a need to limit the size of the building and at the same time to make the best use of the space available, without preventing possible further expansions in the future.

The chapter on "Laboratory Buildings and Their Maintenance" in E. S. Hiscocks's Laboratory Administration (Macmillan, London), which quotes liberally from the report by J. Lorne Gray (National Research Council No. 1913, Technical Report No. 3. Ottawa; January

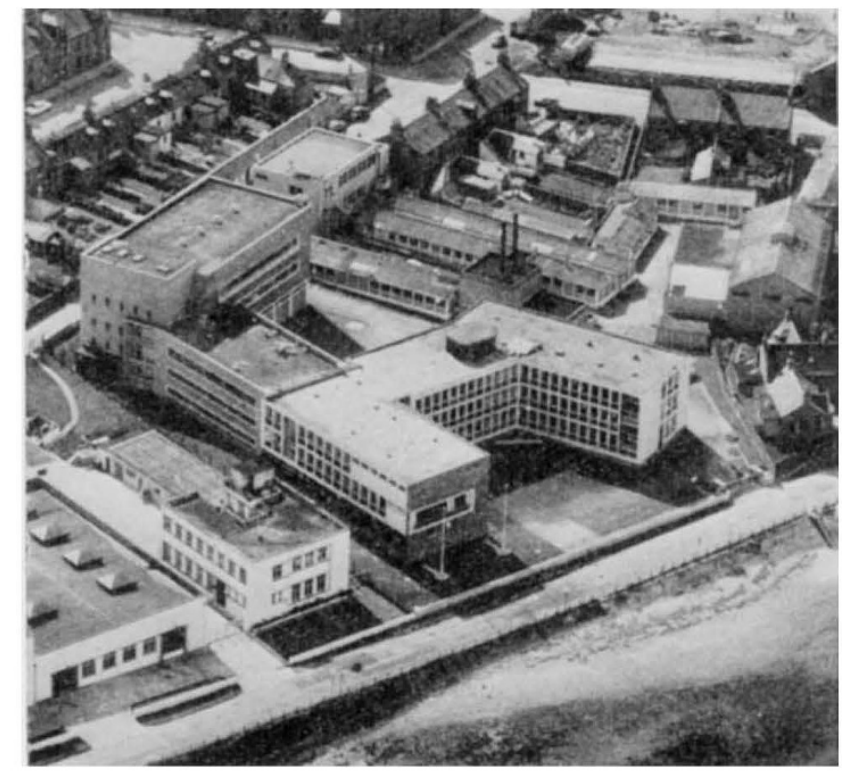

Fig. 1. Aerial view of the Torry Research Station, Aberdeen, and the new extension 
1949) proved most helpful in arriving at a figure for the special roquirements of scientifie workers. The scientists to be housed in the new building included physicists, chemists, biochemists and bacteriologists, and it was decided to use a figure of $400 \mathrm{sq}$. ft. of gross space per worker with a uso factor of 70 per cent as a basis for working out the laboratory space roquirod. Applying the use factor to obtain a figure of $280 \mathrm{sq}$. $\mathrm{ft}$. per worker and making allowances for proposed increases in staff over the noxt 5-10 years and for special requiremonts, tho total area of laboratory space, including ancillary space, worked out at $13,000 \mathrm{sq}$. ft. To this was added 7,900 sq. ft. of administrative office space, based on a requiremont of $150 \mathrm{sq}$. ft. for single rooms and $110 \mathrm{sq}$. ft. per worker for larger officos, and 1,500 sq. ft. oach for library and conforence room. Tho latter was removed from tho schedule at a later stage. The total requirement was thus about $19,500 \mathrm{sq}$. $\mathrm{ft}$., to which had to be added the space required for corridors, toilets and stairways.

At the beginning it bocame evident that the availabls space would best bo used, and flexibility with regard to any modifications that might be required in the future would bost be obtained, by designing a standard main laboratory suitable with minor modifications for all sections and that this in turn would depend on designing a standard working bench.

It was decided that adoquate working space, together with room for fixod and experimental equipmont not roquiring a bench, could be obtainod in a 20 - $\mathrm{ft}$. wide laboratory fitted on tho 'oxtornal' wall with a number of 14 -ft. long by 5 -ft. wide double-sided peninsular bonches $5 \mathrm{ft}$. apart. This arrangement has a numbor of advantages. The maximum benofit is obtained from natural light, sorvicing problems are casily solved by the provision of service ducts on the inside of the walls of the building, a convenient way in any evont for a multi-storoyed building, and spaco hoating can be provided by radiators or convectors on the face of tho service ducts between benches. This mesunt that the distance betweon bench centres would be $10 \mathrm{ft}$., which in turn meant that the distance betwcen structural stanchions would need to be $10 \mathrm{ft}$. also, so as to enable the building to be divided neatly into its componont laboratories. It also meant that laboratories of any length in multiples of $10 \mathrm{ft}$. could be provided as requested. Each laboratory would have two single benchos, ono for each partition wall, and a number of double-sided benches, deponding on the length of the laboratory. In order to restrict the span of the building to a reasonable dimension it was docided to build the main laboratories on one side of the building only and to use the othor side of the central corridor for ancillary rooms. In this way, the span of the building has been kept down to $46 \mathrm{ft}$.

The laboratory bench was designed in close consultation with the staff, and in the final stage a full-sized model was made so that staff and all concerned with tho design and erection of the new building could have the opportunity to make comments. The bench was designed to be fitted with a central service unit 9 in. wide with suitable connexions for joining to the service supplies in the service duct. In the finished bench, tho central unit is carried above the surface of the working bench to provide a 12-in. high upstand on which service outlets to both sides of the bench are fitted. The central unit extends $12 \mathrm{ft}$. from the wall, thus leaving a $2 \mathrm{ft} . \times 5-\mathrm{ft}$. space at the end of the bench, which is taken up by a 20 -in. $\times 14$-in. sink supplied with hot and oold water. Each side of the bench is supplied with six high-pressure water outlets, eight electric power points in four double units and four gas points. In addition, steam and an air or nitrogen line fed by a cylinder of compressed gas within the laboratory aro provided as requested. All the bench tops and central upstands aro finished in plastic.

It was decided to fit nach laboratory with a fume cupboard on one partition wall, and the design by Messrs.
Armstrong (Hull), Lid., was chosen. The cupboards were made $12 \mathrm{ft} .6 \mathrm{in}$. long, divided into two equal sections by a glass partition. Fach section is fitted with a $4 \cdot 5$-in. deep trough and an 8-in. $\times 8$-in. sink. Services, all with frontal control, include gas, water, elcctricity, steam and an oxygen or nitrogen line. Altogether, nine main laboratories ranging in length from 20 to $60 \mathrm{ft}$., fitted in all with 14 double and 10 single benches and 9 fume cupboards, have been provided.

Fig. 2, a sketch plan of new ground-floor laboratories, illustrates the general shape of the new extension and its position in relation to existing buildings. In arriving at this layout, a number of conditions had to be observed. First, the ground floor of the new building had to be level with the ground floor of the earlier extension, which, in fact, is $4 \mathrm{ft}$. below the level of the main building; secondly, the second or top floor had to be made level with the first or top floor of the main building; and thirdly, a pilot scale laboratory with a headroom of about $14 \mathrm{ft}$. had to be provided. All this has boen done satisfactorily, but because there is a headroom of $20 \mathrm{ft}$. or so on the ground floor of the main building and the usual $10 \mathrm{ft}$. or so in the earlier extension, there is no direct link betwoen the new first floor and the main building except by means of the stairway.

For a number of reasons, the two new floors immediatcly above the earlier extension are used for administration offices and library. The distance between structural stanchions in this part of the building is $12 \mathrm{ft} .6 \mathrm{in}$. , which would not have allowed a satisfactory arrangement of laboratories fittod with peninsular benches with centres $10 \mathrm{ft}$. apart. In addition, the provision of the sorviecs required would have presented difficulties.

Sufficient headroom for the pilot-scalc laboratory has been obtained by taking advantage of the slope of the sito. This laboratory and a workshop on the opposite side of the corridor have been located at the 'gable' end of the extension and the floor of that part of the building has been made level with the site at that point. An extra $5 \mathrm{ft}$. of headroom has thus been obtained and, in addition, it has been possible to conform to the recommendation made with regard to firo precautions that a stairway and exit to the building should be provided at that point. The contral corridor has been built with a slope of about 1 in 8 over a length of $36 \mathrm{ft}$. or so, in preference to a stairway, so that apparatus can be moved casily between the workshop and the laboratories at the higher lovel.

Most of the ground-floor area, including the pilot-scale laboratory, is occupied by the Physics Section. The benches supplied in the main laboratories are not of the standard type; all are fitted with teak tops and in general they lack the full range of services, other than electricity, provided in other laboratorics. Of special interest is a screened room, of which the walls, ceiling and floor are covered with sheet copper embedded in the surface finish, thus providing space within the building insulated against radio-frequency noise.

In addition to these laboratories, space has been provided for an extension of the Bacteriology Section, chiefly to accommodato the National Collections of Industrial and Marine Bacteria. The benches provided here, though of tho peninsular typo, aro lower than normal. On the first floor, there are thrce sets of laborutories, a Photographic Section and the administration offices. Laboratories are provided for work on the lipids of fish and on fish meal, for work on the chemical and organoleptic assessment of fish quality, which includes a large room for examinining fish, built against the original gable end of the main building, and for work on the general biochomistry of fish flesh. Tho Photographic Section has two dark-rooms and facilitios for dealing with ciné and still photography. The administration offices include a lurgo generol office and registry, Director's and Deputy Diroctor's offices and a number of other individual rooms. 


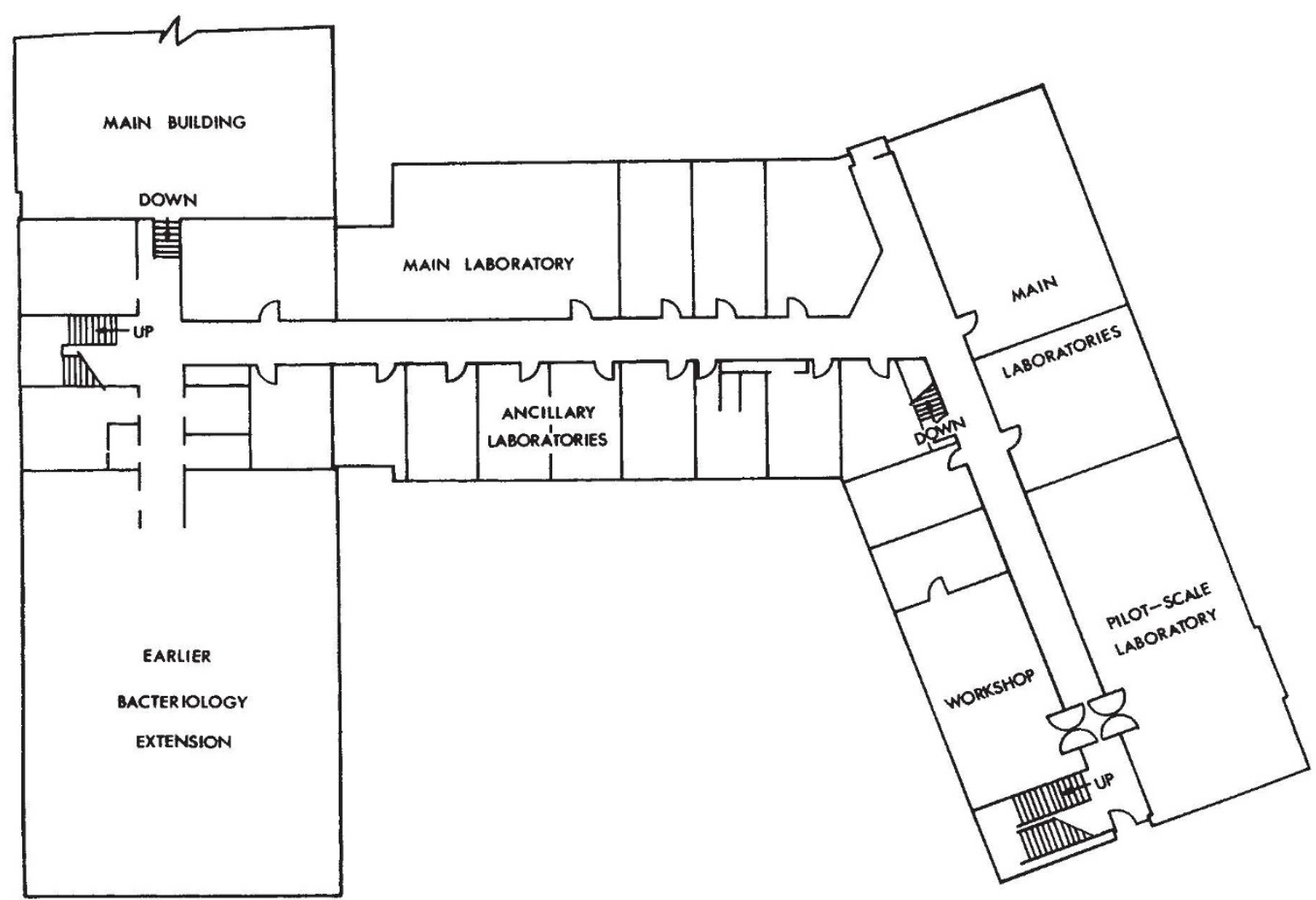

Fig. 2. Sketch plan of ground floor of the new extension to the Torry Research Station showing join to existing buildings

The second floor has laboratories for work on the chemistry of fish steroids and wood smoke, for work on fish muscle proteins, a typing pool, library, and information and liaison offices. The library is situated at the gable end of the extended main building, thus making use of what would otherwise be corridor space. One wall is fitted with high-level windows and the ceiling with six roof lights, $4 \mathrm{ft}$. 6 in. in diameter. The periodical rack is a special feature. All periodicals are shown on a wooden fixture, held sufficiently off the vertical to allow the books to stand without falling off, which pivots on two small projections near the top and which ean therefore be raised and pushed back to obtain access to a boxed-in shelf on which immediate back numbers of the periodicals are kept.
For the first time since the Station was opened in 1929 , all the requirements of its basic and applied work and administration are now accommodated in the one building, having a total floor space of about 55,000 sq. $\mathrm{ft}$. All sections now have ready and easy access to each other and to central services such as library, typing pool and administration offices. This has already led to an increase in efficiency of operation and to an improvement in general morale.

In conclusion, mention must be made of the excellent work of Messrs. A. C. Shallis and S. C. G. Lambert, architects of the Edinburgh Office of the Ministry of Public Buildings and Works, and in particular of their ready willingness at all times to co-operate to the full with the scientific staff to provide the required facilities.

\title{
CORRELATION OF AMINO-ACID COMPOSITION WITH CERTAIN CHARACTERISTICS OF PROTEINS
}

\author{
BY DR. FREDERICK T. HATCH \\ Arteriosclerosis Unit, Massachusetts General Hospital, and Department of Medicine, \\ Harvard Medical School, Boston, Massachusetts
}

$\mathrm{M}$ OST proteins are comprised of a mixture of the same set of twenty natural amino-acids ${ }^{1}$. There is considerable similarity among many proteins in the relative quantities of the various amino-acids ${ }^{2}$. One might therefore consider that a knowledge of the amino-acid composition of a protein would be insufficient to permit the drawing of deductions concerning specific features of its structure or biological function. A further knowledge of the aminoacid sequence, or primary structure, of a protein might be required for this purpose ${ }^{3}$. However, in this communication a series of correlations will be presented between the properties of certain proteins and their composition, when the constituent amino-acids are classified according to their polar or apolar nature*.

For the purposes of this discussion, the following amino-acids have been assigned to a polar group: Asp and Asp $\mathrm{NH}_{2}$, Glu and Glu $\mathrm{NH}_{2}$, Lys, Arg, Ser, Thr ${ }^{5}$. The following amino-acids have been assigned to an apolar group: Val, Leu, Ileu, Met, Pro, Phe. The remaining common amino-acids have not been assigned to either group for reasons to be explained. His and Tyr have been shown to have ambivalent character; in a given protein some residues may reside in the surface and others in the interior ${ }^{6-8}$. The molecular size and polarity of Gly and Ala 